\title{
KONZERVATORSKO-RESTAURATORSKI RADOVI NA MARAMI I ŠALU IZ KRIPTE KATEDRALE SV. TEREZIJE AVILSKE U POŽEGI
}

U prilogu će biti prezentirana konzervatorsko-restauratorska istraživanja i radovi na dijelu grobnog tekstila iz kripte katedrale sv. Terezije Avilske u Požegi. Radovi su provedeni na Odsjeku za tekstil Restauratorskog centra Hrvatskog restauratorskog zavoda u Ludbregu tijekom 2007. i 2010. godine. Stilskom analizom tkanih uzoraka damastnih tkanina marame $i$ šala pokušat će se pobliže odrediti mjesto i vrijeme njihova nastanka.

\section{Sažetak}

Tijekom radova na sanaciji kripte u katedrali sv. Terezije Avilske u Požegi u drvenim ljesovima s posmrtnim ostacima građana i građanki Požege pronađen je velik broj grobnih priloga, pa i odjeća u kojoj su bili ukopani. Među pronađenim tekstilnim predmetima nalazile su se marama pok. Ane Slavetić i šal pok. Ane Erlinger. Marama i šal bili su izrađeni od finih, mekih i sjajnih svilenih damastnih tkanina smeđih tonova s utkanim motivima cvjetnih buketa i čipke. Konzervatorsko-restauratorska istraživanja i komparativne analize tekstilno-tehnoloških i stilskih karakteristika bili su usmjereni na određivanje vrste i podrijetla svilenih tkanina, pa su na temelju dobivenih rezultata datirani u prvu polovicu 19. stoljeća, ali nije bilo moguće utvrditi točno mjesto njihove izrade. Međutim, uspoređujući ih s drugim komparativnim primjerima, može se pretpostaviti da su nabavljene na području srednje Europe, Austrije (Beča) ili Češke, jer je kontinentalna Hrvatska s tim područjima u to doba imala intenzivne gospodarske, trgovinske i kulturne veze.

Zbog uvjeta kojima su tekstilni predmeti unutar ljesova dugo vrijeme bili izloženi tijekom procesa razgradnje tijela, iako prilično dobro očuvani, na marami i šalu bila su prisutna mnogobrojna mehanička oštećenja i fizikalno-kemijske promjene izvornih tonova obojenja. Na Odjelu za tekstil Hrvatskoga restauratorskog zavoda u Zagrebu 2006. godine provedena je faza dezinfekcije, mokrog i suhog čišćenja te sušenja s izravnavanjem cjelokupne zbirke haljina i marama, a tijekom 2009. i 2010. godine konzervatorsko-restauratorski radovi na marami i šalu nastavljeni su na Odsjeku za tekstil Restauratorskog centra Hrvatskog restauratorskog zavoda u Ludbregu. Predmeti su očišćeni od preo- 
stalih čestica nečistoće, tkanine i rese su izravnane te su na njima sanirana mehanička oštećenja kombiniranom tehnikom podlaganja i učvršćivanja šivanjem. Nakon provedenih radova predmeti su vraćeni u Požegu upakirani u kutije od beskiselinskog kartona za pohranu.

Ključne riječi: katedrala sv. Terezije Avilske; grobni tekstil; svileni damast; marama; šal; konzervatorsko-restauratorski radovi.

\section{Uvod}

Tijekom konzervatorskih istraživanja koje je 2006. godine u kripti katedrale sv. Terezije Avilske u Požegi provodio Konzervatorski odjel Ministarstva kulture u Požegi pronađeni su mnogobrojni grobni prilozi, a među njima i velik broj raznovrsnih odjevnih tekstilnih predmeta u kojima su tijekom 19. stoljeća bili ukopani pokojnici iz kruga požeškoga građanstva i svećenstva. Nakon vađenja iz ljesova i separiranja grobnih priloga te odjevnih predmeta od posmrtnih ostataka pokojnika, sedam tekstilnih predmeta koji su se svojim stilskim karakteristikama izdvajali iz cijele skupine - pet haljina te marama i šal - preuzeto je u Hrvatski restauratorski zavod radi konzervatorsko-restauratorskih radova. U prvoj fazi radova 2006. godine djelovalo se na uklanjanje primarnih uzročnika njihova propadanja, čime je stanje tekstilnih predmeta stabilizirano. Mikrobiološka analiza provedena je na Fakultetu kemijskog inženjerstva, pri Zavodu za industrijsku ekologiju, u Zagrebu. Tijekom tih analiza izolirane su razne kulture bakterija i plijesni koje su u okruženju visoke vlage u kripti svojim djelovanjem uzrokovale nepovratnu promjenu obojenja vlakana tekstilnih predmeta. Dobiveni rezultati mikrobiološke analize bili su vrlo važni za definiranje daljnjeg tijeka radova. Prvom fazom sušenja zaustavljen je razvoj mikroorganizama i njihovo štetno djelovanje. Nakon toga predmeti su bili podvrgnuti dezinfekciji radi uklanjanja mikroorganizama. Pranjem i ispiranjem bile su uklonjene nečistoće poput ostataka drvenih čestica, čahurica kukaca te površinske i dubinske prljavštine. Tim je postupkom tkaninama bio vraćen, koliko je to bilo moguće, prirodni sjaj i u manjoj mjeri boja, a vlaknima elastičnost i volumen. Na kraju postupka haljine su osušene na lutkama kako bi im se vratila voluminoznost, a relaksiranjem su maramama izravnani nabori i struktura tkanja. ${ }^{1}$

U drugoj fazi radova pet izdvojenih haljina restaurirano je na Odjelu za tekstil Hrvatskog restauratorskog zavoda u Zagrebu, dok su marama i šal iz kompleta dviju haljina pokojne Ane Erlinger i pokojne Ane Slavetić prošli drugu fazu restauratorskog postupka na Odsjeku za tekstil Restauratorskog centra Hrvatskog restauratorskog zavoda u Ludbregu. Paralelno s konzervatorsko-restauratorskim radovima

\footnotetext{
Nužni konzervatorski postupci na tekstilnim predmetima iz kripte katedrale sv. Terezije u Požegi /plakat/. (2014) Zagreb: Hrvatski restauratorski zavod - Odjel za tekstil.
} 
provedena su i povijesno-umjetnička i tehnološka istraživanja tkanina od kojih su marama i šal bili izrađeni pri čemu su korišteni razni izvori i stručna literatura o tekstilnoj tehnologiji, katalozi izložbi građanskog ruha, a proučena je i dostupna komparativna muzejska građa.

\section{Povijesno-modni kontekst (Laver, 1988.)}

Modni detalji poput rubaca, marama i šalova bili su vrlo omiljeni u prvoj polovini 18. stoljeća. U primjeni im je prethodio veći ili manji četvrtasti komad bijele lanene tkanine, muslina ${ }^{2}$ ili svile, zvan fich $u^{3}$ (fotografija 1), koji se naboran omatao oko vrata ili su se njime ogrtala ramena zaklanjajući duboki dekolte. Takav način nošenja davao je i pomalo erotski naboj jer se dekolte mogao prekriti u manjoj ili većoj mjeri, a za izradu tih predmeta često su se koristile vrlo transparentne tkanine

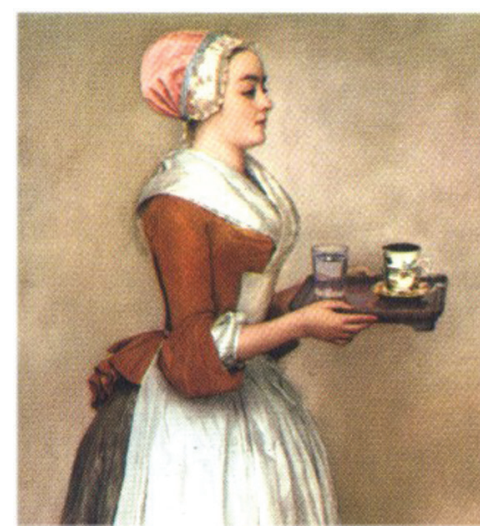

Fotografija 1. Fishu na dekolteu žene, 18. stoljeće (presnimljeno iz: Laver, 1988.)

2 Muslin je vrsta pamučne tkanine za koju se vjeruje da potječe iz grada Mosula (današnji Irak), po kojem je izveden njezin naziv. No, smatra se da je porijeklo te tkanine dalje na istoku, u Aziji. Rani indijski muslin bio je ručno tkan od izuzetno fine, rukom uvijene pređe. U Europu je uvezen tijekom 17. i 18. stoljeća iz indijske regije Bengal (odnosno iz grada Dhake u današnjem Bangladešu), gdje se upotrebljavao za izradu sarija. Nešto kasnije počeo se proizvoditi u škotskim i engleskim manufakturama. Muslin je uglavnom ravna, glatka, pamučna tkanina tkana u platnenom vezu od vrlo finih niti osnove i potke. Ima je u različitim debljinama. Muslin bolje kvalitete fine je i glatke teksture i tkan je od ravnomjerno predenih ili oplemenjenih niti osnove i potke kojima je dobivena mekana završna tekstura. Takvi muslini mogu biti bijeljeni ili obojeni nakon tkanja, ponekad s utkanim uzorkom ili otisnutim nakon tkanja. Grublje varijante često su od neujednačenih niti pređe i grublje su teksture. https://www.britannica.com/ print/article/399430 8.2.2020; https://en.wikipedia.org/wiki/Muslin/ 8. 2. 2020.

3 Fichu je mala trokutasta marama, najčešće bijela, ponekad crna, od čipke ili finog lanenog platna (batista). Ta varijanta marame imala je određenu namjenu. Kako je vratni izrez na haljinama postajao sve veći i niži, fichu se vezao oko vrata, a nabori vrhova padali su joj između prsa zaklanjajući ih. Vrlo otvoreni vratni izrezi prekrivali su se i kratkim pelerinama, tzv. fichu-pelerinama. (Laver, 1988.). 
s čipkom. Šezdesetih godina 18. stoljeća započeli su prvi pokušaji uvođenja novog stila odijevanja. Suštinska promjena sastojala se od slabljenja utjecaja mode francuskog dvora i sve većeg utjecaja engleske ladanjske odjeće. Bila je naglašena tendencija prema jednostavnosti i praktičnosti. Sedamdesetih godina 18. stoljeća javljaju se značajne promjene u vanjskoj liniji ženske odjeće, dok gornji dio haljine još zadržava vrlo dubok dekolte ispunjen maramom ili šalom. Odbačeni su bili koluti, umetci i korzeti te teški i raskošni materijali. Svila je zamijenjena dražima pamučnih materijala iz Engleske. Ženska odjeća tog doba bila je manje ekstravagantna i pokazala je drastičan otklon od prošlosti. Žene su nosile haljine koje su bile toliko prozračne, čak prozirne, da su djelovale poput spavaćica ili donjeg rublja s obzirom na to da su bile sašivene od finih tankih tkanina poput muslina, batist $a^{4}$ ili $k a l i k a^{5}$. Imale su visoko postavljen struk i ekstreman dekolte, čak i u dnevnoj varijanti, a sezale su do poda (fotografija 2). Kraj 18. stoljeća donio je opsjednutost čipkom te se ona počela javljati kao sastavni element i ukras samih tkanina. Uspon bogatih buržuja i građana krajem 18. stoljeća okarakteriziralo je društvo i modu kroz nadolazeće 19. stoljeće. Tijekom prvog desetljeća 19. stoljeća vanjska linija ženske odjeće nije se drastično mijenjala, osim duljine suknje. U modu su ponovno došli nabrani ovratnici, a pojavila se i velika strast za šalovima, posebno kašmirskim ili rađenim po uzoru na njih. Europske zime bile su prehladne za tanke materijale od kojih su se izrađivane haljine, pa su kašmirski šalovi postali neizostavan element, ne samo u funkciji ogrtanja tijela radi zaštite od hladnoće već i kao modni dodatak koji je upotpunjivao haljinu. Svaka žena koja je držala do mode nosila je šal s ponosom te je on predstavljao jedan od najbitnijih dijelova ženske garderobe. Prva četvrtina 19. stoljeća bilo je razdoblje koje je unijelo velike promjene na ženskoj haljini (fotografija 3). Struk se ponovno vratio na mjesto i postao sve uži. Da bi se postigao što uži struk, u modu su ponovno ušli i korzeti. Mijenjao se i oblik rukava. U početku su to bili mali i kratki rukavi nabrani tik do ramena, kojima su oko kraja prve četvrtine 19. stoljeća dodani još jedni veći od prozirne tkanine (fotografija 4). Na večernjim haljinama dekoltei su bili ekstremni,

4 Batist / batiste, cambric / jest ravnomjerno tkana, fina tkanina izrađena od pamuka ili lana poput cambrica, što je sinonim za francusku riječi batiste. Batist se često koristi kao tkanina za podlaganje visokokvalitetne odjeće. Koristi se i za izradu rupčića (pamučni batist) i donjeg rublja (svileni batiste). Rječnik engleskog jezika dvadesetog stoljeća braće Cambers definira batist kao „uobičajeni francuski naziv za cambric" i koristi se u trgovini za "fine teksture lana i pamuka“. https://stylerevolution.github.io/ textilegloss/ 14. 9. 2020., https://en.wikipedia.org/wiki/Batiste / 2008.

5 Kaliko /engl. Calico/ potječe iz Kalkute, grada u jugozapadnoj Indiji, po kojem dobiva ime, a poznat je već u 11. stoljeću pod lokalnim nazivom caliyans jer ga je tkala kasta caliyan. Trgovci ga donose u Europu tijekom 17. stoljeća. To pamučno platno izrađeno je od nebijeljenog i često nepotpuno obrađenog pamuka, pa može sadržavati i komadiće ljuski. Ta je tkanina manje fina od muslina, ali tanja je od jedrovine ili denima, te je vrlo jeftina kad je neobojena i sirove teksture. Sirova tkanina bojila se i ukrašavala tehnikom tiska u svijetlim bojama, pa tisak na kaliku postaje popularan i u Europi. https:// stylerevolution.github.io/textilegloss/14. 9. 2020. https://en.wikipedia.org/wiki/Calico / 8. 2. 2020. 


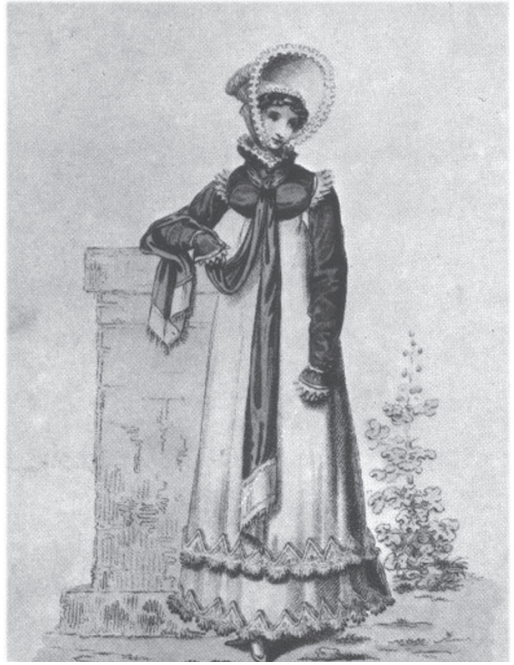

Fotografija 2. Ženska moda s početka 19. stoljeća (presnimljeno iz: Laver, 1988.)

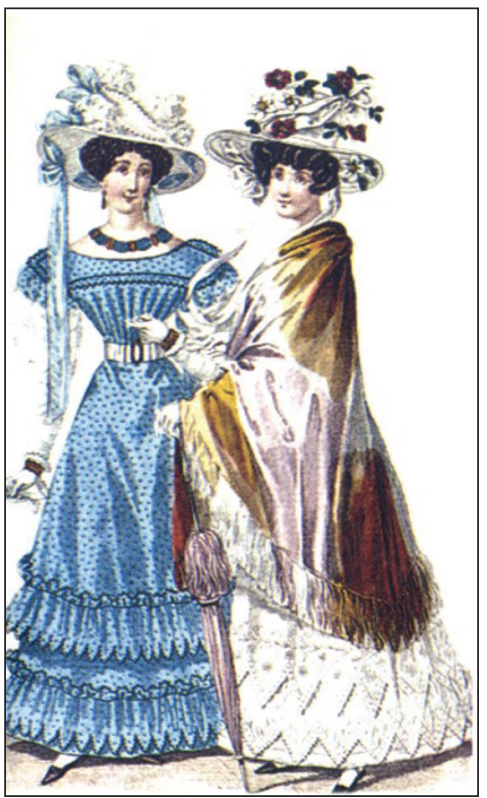

Fotografija 4. Ženska moda oko 1830.-40. godine (presnimljeno iz: Laver, 1988.)

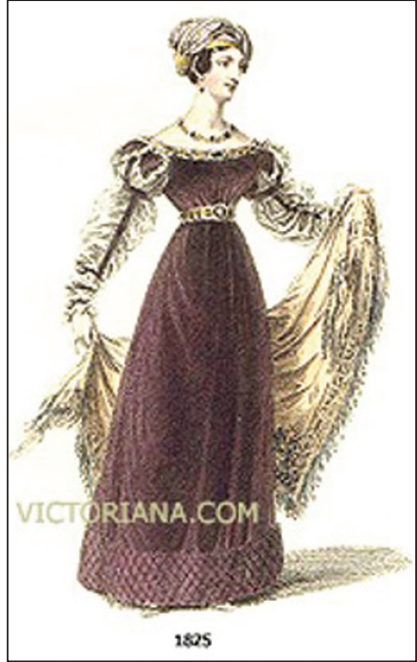

Fotografija 3. Ženska moda u otprilike 1. četvrtini 19. stoljeća (presnimljeno iz: www.victoriana.com/ Shawls/cashmere-shawl.html)

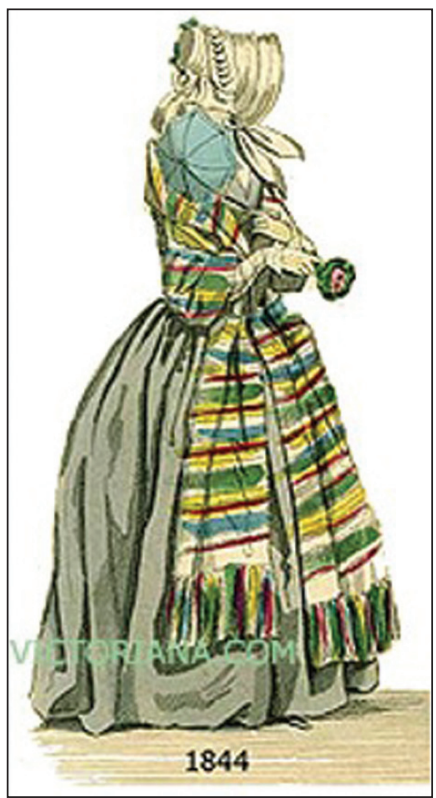

Fotografija 4a. Ženska moda oko 1844. godine. (presnimljeno iz: http://www.victoriana.com/ Shawls/cashmere-shawl.html) 
sezali su do ruba korzeta, a obnažena ramena prekrivala su se širokim i ravnim ovratnicima, „pelerinama“. Ako je takva pelerina imala krajeve koji vise na prsima, nazivala se fichu-pelerina. Šalovi su se nosili, ali nisu bili popularni i moderni kao u prethodnim razdobljima. Nakon 1830-ih romantični kićeni stil u modi se promijenio. Umjesto svijetlih boja prevladavali su tamni tonovi zelene i smeđe, a šalovi su ponovno postali omiljeni modni dodatak. Društveni događaji nakon 1840. utjecali su i na položaj i tretman žena u društvu. Čak je i odjeća dobila zadaću da ženu učini što je moguće „manjom“ (neprimjetnom). U tom periodu žene nose odjeću kojom su bile potpuno prekrivene, izuzev večernjih haljina, kojih su dekoltei oblikovani ravno poprijeko ramena. Glave su se pokrivale šeširićem koji bi ih zaklanjao od pogleda sa strane (fotografija 4a). Šalovi su i dalje ostali popularni, vrlo veliki is resama na rubovima. Zbog egzotičnih uzoraka i privlačnih boja, bili su omiljeni dodatak uz jednostavnu haljinu. Nakon 1830. godine sve se više širi popularnost kašmirskih ${ }^{6}$ šalova čak i među običnim pukom, tako da su do 1840. godine velike industrije šalova nicale po Francuskoj i Engleskoj ${ }^{7}$ kako bi zadovoljile potražnju na tržištu. No, između šalova proizvedenih u Kašmiru i njihovih europskih inačica postoje dvije osnovne razlike. Kašmirski šalovi istkani od kozje dlake lakši su i glađi s prirodnim sjajem, dok su europski šalovi sve do kraja 1830-ih istkani od svile ili vune, što ih čini mnogo težim i ne toliko finim. Razlikuju se i po načinu tkanja, jer su kašmirski šalovi tkani tehnikom koja se podudara s europskom tehnikom tkanja tapiserija. Pomodnost kašmirskih šalova nastavila se sve do perioda Drugog Carstva ${ }^{8}$, kada su predimenzionirane verzije nošene uz krinoline (fotografija 5), pa su postale dominantne

\footnotetext{
Tradicija proizvodnje šalova u Kašmiru postoji od 11. stoljeća, a industrijska proizvodnja razvijala se od 15. stoljeća i u 16. stoljeću. Pravi kašmirski šalovi iz Indije ili Kašmira rađeni su od dlake kašmirske koze. Najraniji dizajn šalova zabilježen je u 17. i 18. stoljeću, a predstavljao je biljku u cvatu zajedno s korijenom. Inspiracija je dolazila iz engleskog herbarija koji je došao do mogulskog dvora tijekom 17. stoljeća. Motiv je postupno evoluirao u uspravnu cvjetnu grančicu, a oko 1800. godine postaje stilizirani motiv češera koji se naziva Paisley bor. Konačno, motiv se promijenio od malog zdepastog češera do vrlo izdužene zaobljene forme. Kašmirske marame u Englesku prvi donose kao poklon iz Indije oko 1775. godine istraživači, predstavnici kompanija u Istočnoj Indiji i vojni dužnosnici koje je očarala njihova ljepota i toplina. U Parizu su se pojavili 1787. godine posredovanjem ambasadora. Međutim, $\mathrm{u}$ francusku modu infiltrirali su se nakon što ih je Napoleon donio u Francusku po povratku sa svog pohoda na Egipat. www.victoriana.com/Cashmere/Cashmere-shawls.html / 2008.

7 Šalovi se u samom vrhu europske mode zadržavaju gotovo 100 godina, od 1780-ih do 1870-ih. Tijekom tog razdoblja proizvodnja tkanih šalova s izvezenim ili tiskanim uzorkom tzv. paisley ornamenta širi se od Kašmira, Perzije, Indije, Rusije, SAD-a pa do Europe: u Francusku (Pariz, Lyon), Austriju (Beč) i Englesku (Norwich) te Škotsku (Edinburgh, Glasgow, Paisley). U Paisleyju su se šalovi proizvodili na najekonomičniji način i kroz najduži period. Šalovi proizvedeni u tom škotskom tkalačkom centru nisu se smatrali pukom zamjenom onih kašmirskih. www.victoriana.com/Cashmere/Cashmereshawls.html / 2011.

8 Drugo Carstvo imperijalni je bonapartistički režim Napoleona III. koji je trajao 1852. - 1870. godine, između Druge i Treće Republike u Francuskoj. https:// www. enciklopedija.hr/natuknica.aspx?id=42928 / 14. 9.2020.
} 
u modnom stilu. Slijed događaja od 1870-ih nadalje doveo je do pada popularnosti velikih šalova i marama jer su postale toliko jeftine da si ih je mogla priuštiti gotova svaka žena, pa su pomalo izašle iz mode.

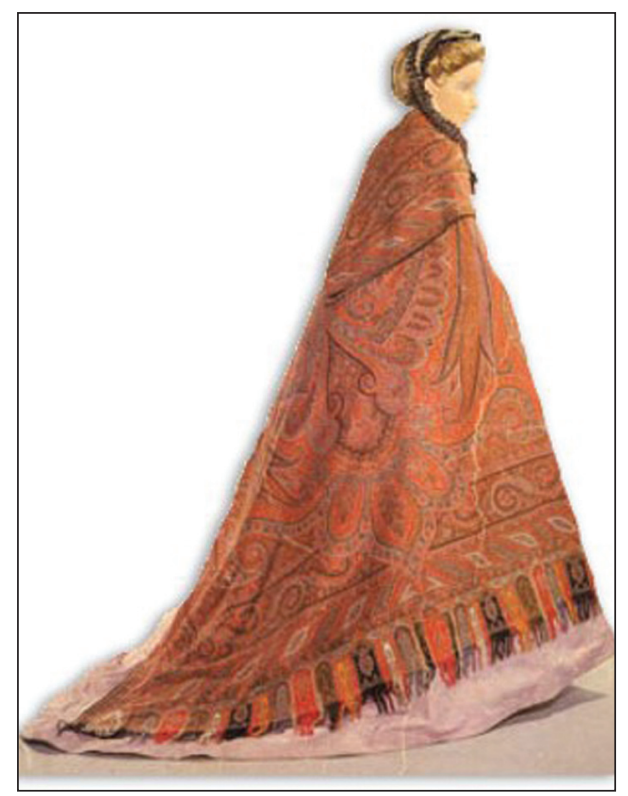

Fotografija 5. Ženska moda u 2. polovici 19. stoljeća (presnimljeno iz: Laver, 1988.)

\section{Marama pok. A ne Slavetić ${ }^{9}$}

\section{Opis marame (fotografija 6)}

Marama pokojne Ane Slavetić ima oblik četverokuta velikih dimenzija, a izrađena je od svilenog damasta tamnosmeđe boje te je ukrašena resama od tamnosmeđeg, svilenog konca izvedenima tehnikom uzlanja. Tkanina ima utkani uzorak koji teče kontinuirano uz rubove marame, a ima oblik čipkasto-cvjetne bordure. Unutar te bordure u pravilnom su rasteru razasuti stručci cvijeća. Marama je nepoznate provenijencije, a budući da je pronađena uz haljinu širokih, nabranih rukava, uska struka i bogato nabrane široke suknje, datirana je u vrijeme oko 1830 . godine. ${ }^{10}$

9 Izvješće o provedenim konzervatorsko-restauratorskim radovima na marami Ane Slavetić iz kripte katedrale sv. Terezije Avilske u Požegi. (2008.) Ludbreg: Hrvatski restauratorski zavod - Restauratorski centar Ludbreg.

10 Izvješće o provedenim konzervatorsko-restauratorskim radovima na grobnom tekstilu iz kripte katedrale sv. Terezije Avilske, Požega (haljina Ane Ljubić, haljina i marama Ane Slavetić) (2008.) Zagreb: Hrvatski restauratorski zavod - Odjel za tekstil. 


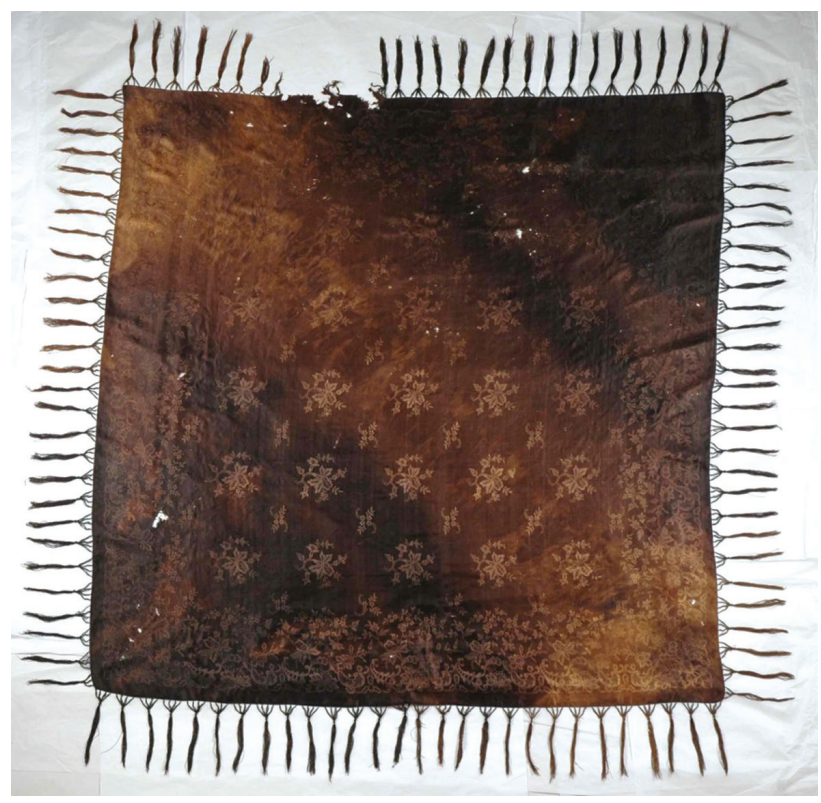

Fotografija 6. Marama, prije radova (iz fotoarhiva HRZ-a, J. Kliska, 2007.)

\section{Tekstilno-tehnološke karakteristike marame}

Dimenzije marame četverokutnog oblika su 150 x $150 \mathrm{~cm}$. Za njezinu izradu korištena je damastna tkanina glatke i sjajne površine, koja je u podlozi istkana $\mathrm{u}$ osnovnom atlasnom vezu, dok su utkani uzorci cvjetno-čipkastih motiva u potkinu atlasnom vezu s mat efektom. Uzorak cvjetno-čipkaste bordure, koja teče kontinuirano uz rubove marame, širok je 20,5 cm, a od samog ruba tkanine odmaknut je 3,5 $\mathrm{cm}$ (fotografija 7$)$. Manji $(5 \times 7 \mathrm{~cm})$ i veći $(11 \times 13 \mathrm{~cm})$ stručci cvijeća po površini su unutar bordure raspoređeni naizmjence u pravilnim redovima. Tkanina s dvije nasuprotne strane završava živim rubom bez poruba, dok je s druge dvije nasuprotne rezana i porubljena dvostruko podvijenim rubom koji je sašiven ručno tamnosmeđim koncem ravnim bodom dužine $1-3 \mathrm{~mm}$ (fotografija 8 ).

Rese na sve četiri strane marame grupirane su u 28 kićanki na sljedeći način:

na svaki $1 \mathrm{~cm}$ razmaka kroz rub tkanine provučeno je 5 niti presavijenih napola (dužine $16-17 \mathrm{~cm}$ ) koje na taj način tvore jednu resu od 10 niti povezanih malim čvorićem tik uz rub tkanine. Po četiri takve resice u nizu povezane su većim čvorom na udaljenosti $3 \mathrm{~cm}$ od ruba tkanine i tvore jednu veću i deblju resu / kićanku. Na trima stranama marame ima 28 kićanki, a na četvrtoj ih je 29. 


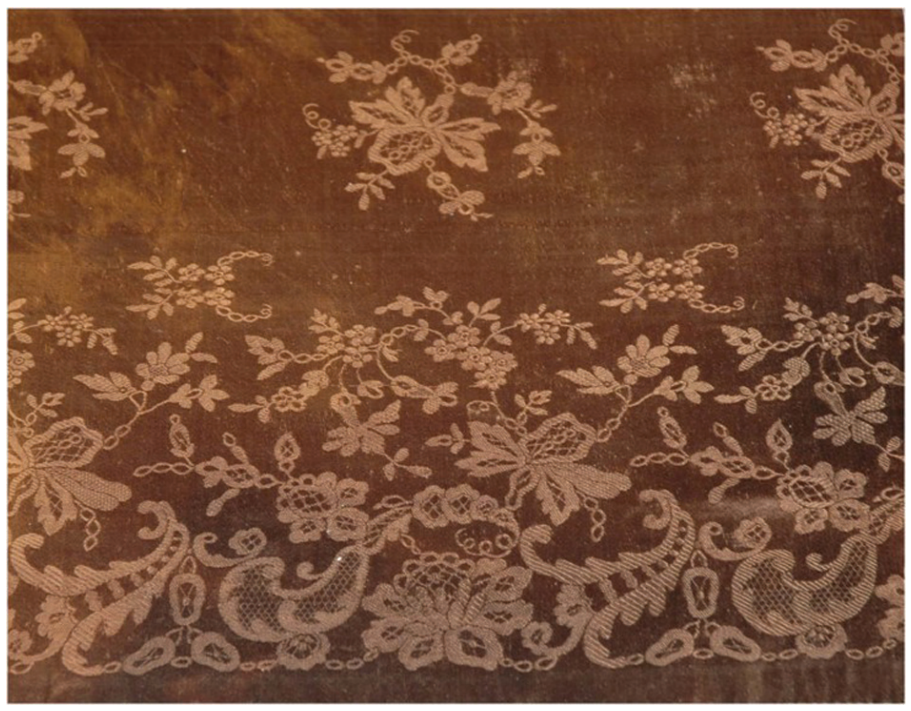

Fotografija 7. Marama, detalj tkanog uzorka (iz fotoarhive HRZ-a, J. Kliska, 2007.)

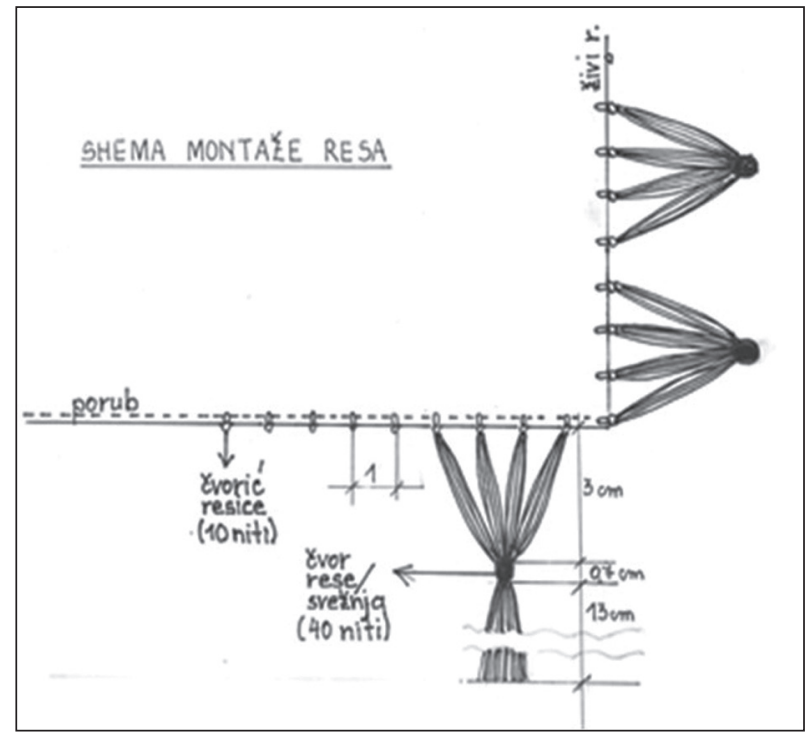

Fotografija 8. Marama, grafički prikaz konstrukcije resa (izradila: V. B. Vučković, 2007.) 


\section{Opis zatečenog stanja}

Nakon prve faze radova - nužnih konzervatorskih postupaka dezinfekcije, mehaničkog uklanjanja nečistoće, mokrog čišćenja i izravnavanja - provedene tijekom 2006. godine marama je bila zatečena u sljedećem stanju (fotografija 9):

- bila su vidljiva fotokemijska oštećenja tkanine i tekstilnih niti;

- na tkanini i resama nastale su promjene izvornog tona obojenja u vidu dijagonalnih pruga. Promjena obojenja najvjerojatnije je nastala kao posljedica neposrednog kontakta tkanine s ljudskim tijelom prilikom procesa raspadanja jer je marama bila presavijena u trokut i tako prebačena oko vrata i leđa pokojnice. Izvorna tamnosmeđa boja mjestimice je posvijetljela, a raspon vidljivih tonova ide od tamnosmeđe preko crvenosmeđe do svijetlog okera;

- niti osnove i potke bile su prekinute ili razmaknute ili su u potpunosti nedostajale, pa se mnogobrojni manji i veći otvori vide po cijeloj površini tkanine (vidi skicu oštećenja); (fotografije 10, 11)

- niti osnove i potke svilene tkanine, kao i tekstilne niti resa bile su oslabljene i istrošene, pa je na tim mjestima tkanina bila tanja i prozirna, a rese stanjene;

- na jednoj od strana marame nedostajale su dvije rese, dok su tri bile djelomično sačuvane;

- tekstilne niti bile su mjestimično oslabljene, zapetljane te onečišćene ostacima čahurica i skorenom prljavštinom;

\section{Provedeni konzervatorsko-restauratorski radovi}

Tijekom 2007. godine konzervatorsko-restauratorski radovi na predmetu nastavljeni su na Odsjeku za tekstil Restauratorskog centra u Ludbregu, a tekli su po određenim fazama sljedećim redom. ${ }^{11}$

a) Čišćenje tkanine

Iako je pranje i čišćenje već provedeno u prvoj fazi radova, na pojedinim dijelovima tkanine bilo je još zaostalih čahurica i stranih vlakana te pokidanih i oštećenih / oslabljenih niti koje su se ispreplele s tkanom strukturom. Postupak čišćenja izveden je pomoću pincete odvajanjem i izvlačenjem nečistoće.

b) Ravnanje tekstilnih niti tkanine

Tkanina marame bila je iskrivljene strukture s nitima osnove i potke u izvitoperenom položaju, pa ih je bilo potrebno izravnati. Ravnanje niti povijesnog tekstila moguće je samo kad su one vlažne. Postupak vlaženja (relaksiranja) izveden je u zatvorenom sistemu napravljenom pomoću bugačice ovlažene destiliranom vodom,

11 Radove su izvodile: Venija Bobnjarić-Vučković (konzervator savjetnik i voditelj radova), Vesnica Abramović, (restaurator viši tehničar) i Maja Vrtulek (viši konzervator-restaurator). 


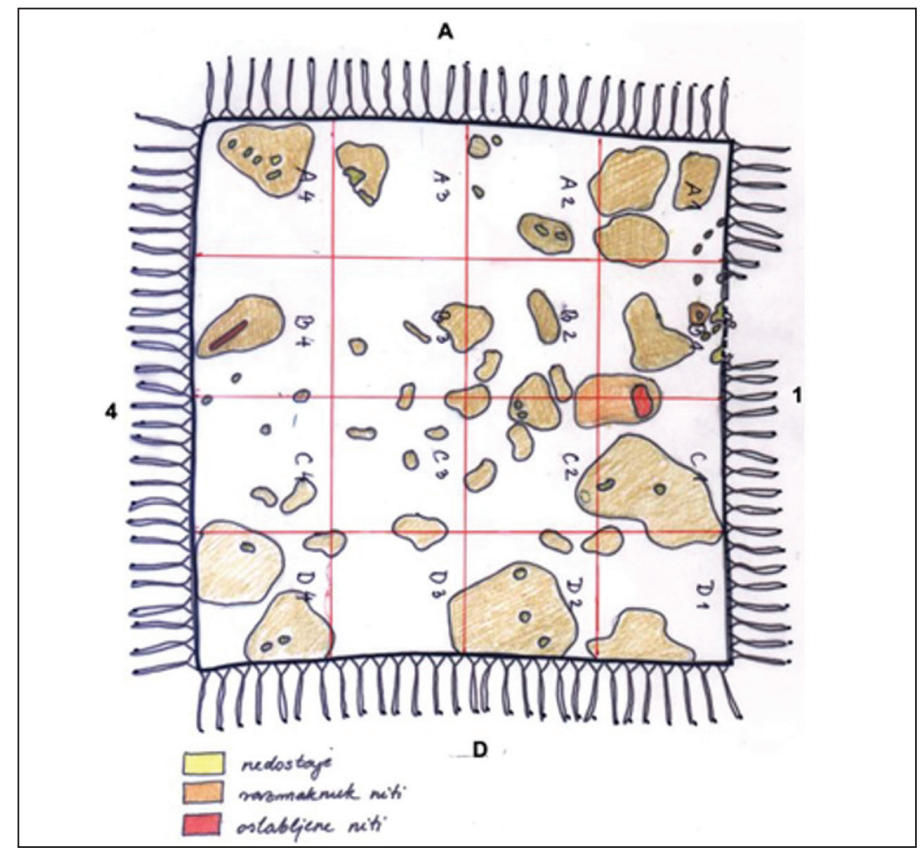

Fotografija 9. Marama, grafički prikaz mehaničkih oštećenja (izradila: V. B. Vučković, 2007.)

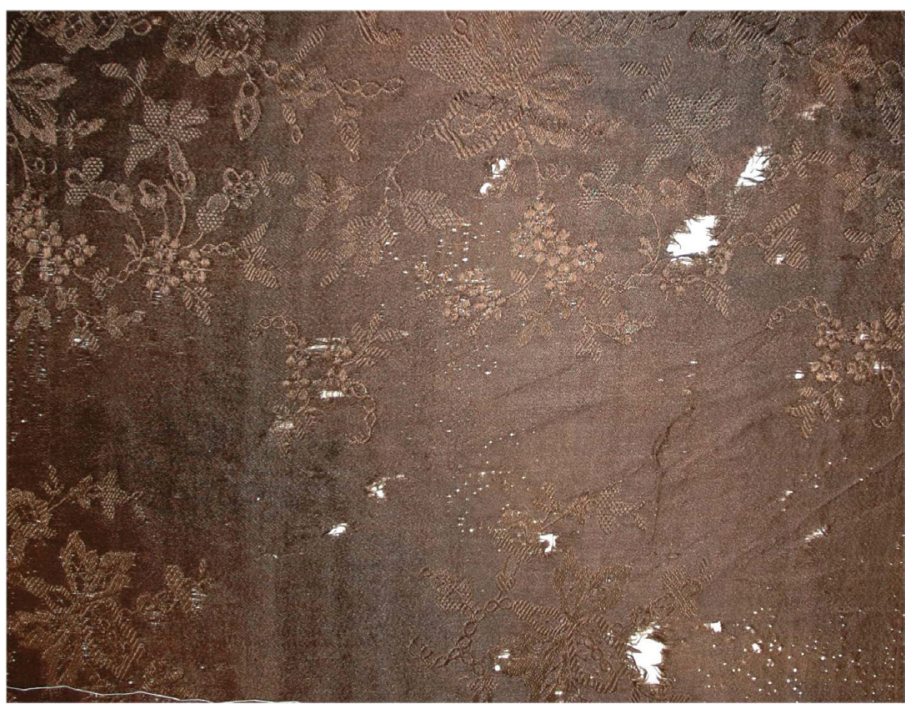

Fotografija 10. Marama, detalj mehaničkog oštećenja tkanine (iz fotoarhiva HRZ-a, V. B. Vučković, 2007.) 


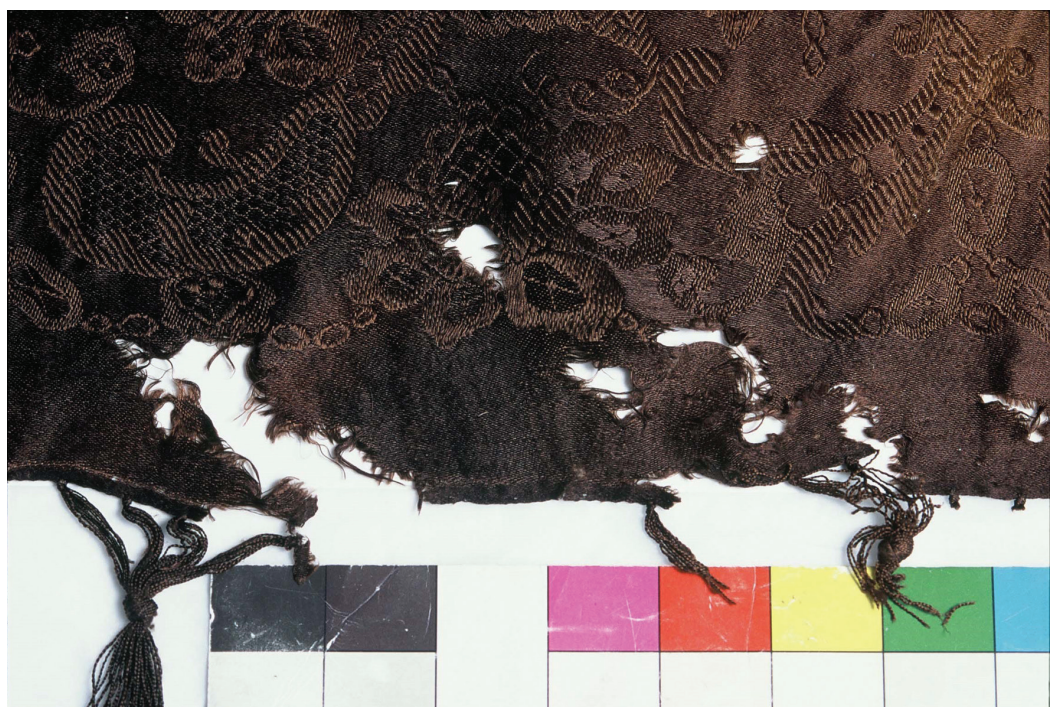

Fotografija 11. Marama, detalj oštećenja rubnog dijela I resa (iz fotoarhiva HRZ-a, V. B.Vučković, 2007.)

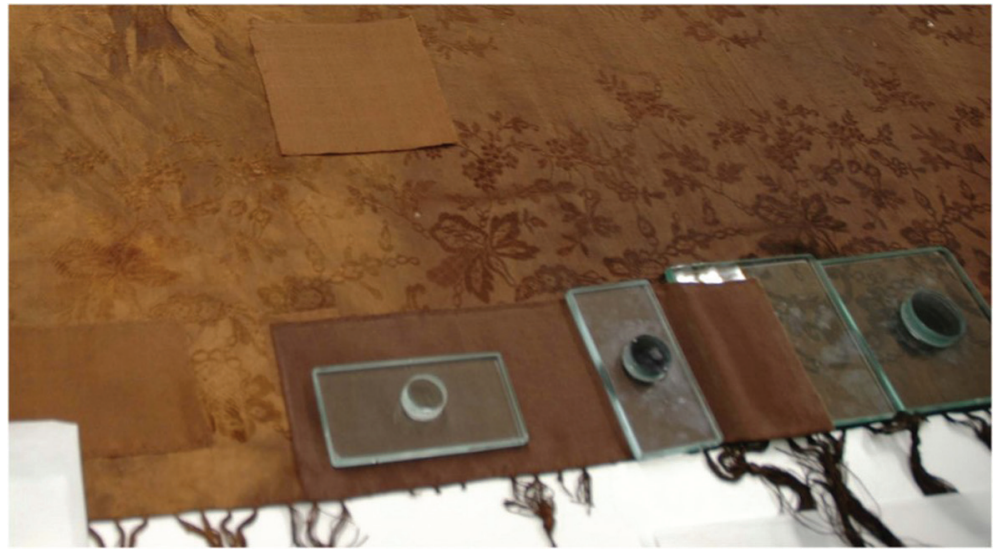

Fotografija 12. Marama, ravnanje i sanacija oštećenja (iz fotoarhiva HRZ-a, V. B. Vučković, 2007.) 
Simpatex membrane i Melinex folije. Nakon toga su ovlaženi dijelovi sistema osnovnih i potkinih niti izravnani debelom tupom iglom i potom opterećeni stakalcima sve dok se nisu osušili (fotografija 12).

c) Bojenje tkanine za podlaganje i šivanje

Za potrebe podlaganja marame na mjestima oštećenja pripremljena je nova svilena tkanina prihvatljivih svojstava tvorničkog naziva Epinal. S tkanine je prethodno ispiranjem uklonjena apretura ${ }^{12}$, nakon čega je izravnana i osušena na glatkoj, ravnoj podlozi.

Postupku bojadisanja obavezno prethode probe. Napravljeno je devet proba bojadisanja te je izabrano sedam smjesa bojila u kojima je bojadisana svila za podlaganje.

Kupke za bojadisanje sadržavale su destiliranu vodu, sol i ocat za postizanje postojanosti i sjaja obojenja te boje u prahu Marabu leicht $\mathcal{E}$ bunt - Batik und Färbefarbe (narančastocrvena, zelenkasta, tamnosmeđa, zelenosmeđa, smeđa i crna). ${ }^{13}$ Obojeni su komadi tkanine veličine 30 × $92 \mathrm{~cm}$ i $60 \times 92 \mathrm{~cm}$.

d) Zatvaranje oštećenja kombiniranom tehnikom (fotografija 13)

Oštećenja tkanine sanirana su polaganjem većih ili manjih dijelova bojene svile na poleđinu oštećenja. Na mjestima gdje je nedostajao veći dio originalne tkanine svila za podlaganje položena je u dvostrukom sloju radi postizanja efekta punine, odnosno gustoće, dok je na mjestima manjih oštećenja svila položena u jednom sloju. Svaki komad nove svile za podlaganje prethodno je ručno obrađen po rubovima svilenim filamentom bodom obameta. Potom su rubni dijelovi podložene svile učvršćeni za izvornu tkaninu svilenim filamentom odgovarajućeg tona ručnim šivanjem kosim bodom u razmaku od cca $5-10 \mathrm{~mm}$. Nakon fiksiranja fragmenta nove svilene tkanine na poleđinu marama je namotana na valjak i pažljivo okrenuta licem prema gore. Saniranje oštećenja nastavljeno je na licu tkanine ručnim šivanjem konzervatorskim bodom. Manja oštećenja sanirana su učvršćivanjem rubova izvorne tkanine za novu, podloženu svilenu tkaninu svilenim filamentom odgovarajućeg tona ručnim šivanjem kosim bodom. Veća oštećenja sanirana su učvršćivanjem obaju slojeva tkanina površinom cijelog oštećenja ručnim šivanjem konzervatorskim bodom svilenim filamentom odgovarajućeg tona (fotografije 14 i 14 a, 15).

12 Apretura (franc. apprêter: pripraviti) završni je postupak oplemenjivanja tekstilnih materijala, također i sredstva za oplemenjivanje, kojima se materijalima daju konačna svojstva i izgled. Osim na tekstilne materijale, apretura se odnosi i na proizvode od papira, kože i krzna. https://www.enciklopedija.hr/ natuknica.aspx?id=3404 / 14. 9. 2020.

13 Originalni tvornički nazivi bojila u prahu iz serije Marabu leicht \& bunt - Batik und Färbefarbe su: cognac, sapin, dunkel braun, koffee braun, mittel braun i schwarz. 
e) Saniranje oštećenja na resama

Budući da su rese bile isprepletene i slijepljene, jer je na njima bilo još zaostalih komadića čahurica i otpalih, odumrlih vlakana, na njima je izvedeno relaksiranje, dodatno čišćenje, ravnanje i završno konzerviranje stanja. Rese su postavljene na vlažnu bugačicu, a postupak prijenosa vlage trajao je nekoliko sati. Nakon toga su očišćene (uklonjeni su ostaci čahurica i odumrlih vlakana tkanine), zatim su raščešljane i izravnane stavljanjem pod stakleni uteg dok se ne osuše. Nakon sušenja prišlo se završnom konzerviranju stanja. Nedostajući dijelovi resa nisu nadomještani. Većina sačuvanih resa imala je manja oštećenja. Sanirani su samo prekinuti ili oslabljeni dijelovi. Prekinuti dijelovi spojeni su i učvršćeni ručnim šivanjem, a oslabljeni su dijelovi sanirani i ojačani dodavanjem končane niti odgovarajućeg tona i učvršćivanjem pomoću svilenog filamenta.

f) Izrada fotografske i grafičke dokumentacije

Prije početka radova i tijekom radova vođena je detaljna fotografska dokumentacija. Za potrebe izrade što točnije fotografske i grafičke dokumentacije na površini marame bijelim koncem napravljen je raster od 16 manjih kvadratnih polja (4 x 4 označenih kombinacijom slova i brojeva A, B, C, D; 1, 2, 3, 4). Svako je polje zasebno fotografirano prije i nakon zatvaranja oštećenja, a na shemi marame s rasterom grafički su zabilježene vrste oštećenja i njihova rasprostranjenost. Raport tkanine s uzorkom cvjetne bordure i cvjetnih buketa iscrtan je na Melinex foliju i paus papir. Nakon zatvaranja oštećenja izrađen je grafički prikaz zatvaranja oštećenja prema upotrijebljenim tonovima svile. Izrađena je skica montaže resa. Nakon završetka radova marama je fotografirana $u$ totalu i detaljima.

g) Pakiranje i transport

Za potrebe sigurnog transporta i privremenog čuvanja marama je zapakirana. Ispod i preko marame postavljen je po jedan sloj beskiselinskog papira. Posebna pažnja posvećena je resama koje su prethodno izravnane i zasebno omotane. Plastična cijev promjera $20 \mathrm{~cm}$ obložena je vatelinom i beskiselinskim papirom te je marama na nju namotana. Marama je završno zaštićena zračnom folijom i ljepljivom papirnatom trakom. Na foliju je pričvršćena fotografija s osnovnim podacima o marami. 


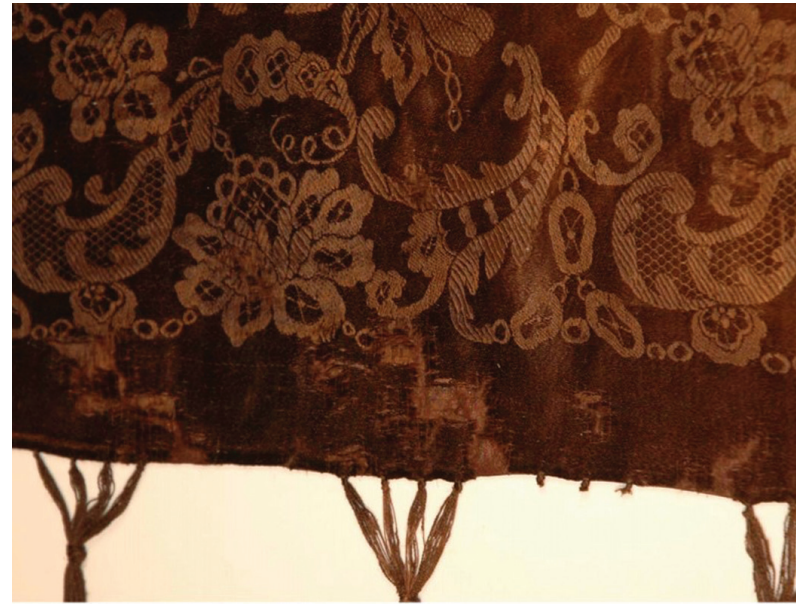

Fotografija 13. Marama, rubni dio nakon sanacije oštećenja (iz fotoarhiva HRZ-a, V. B. Vučković, 2007.)

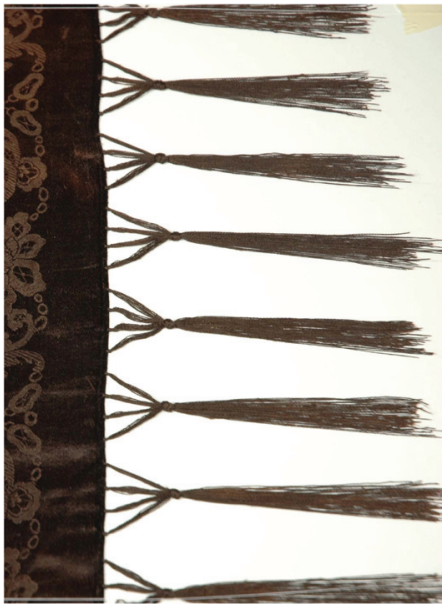

Fotografija 13.a. Marama, detalj resa nakon ravnanja i sanacije (iz fotoarhiva HRZ-a, V. B. Vučković, 2007.)

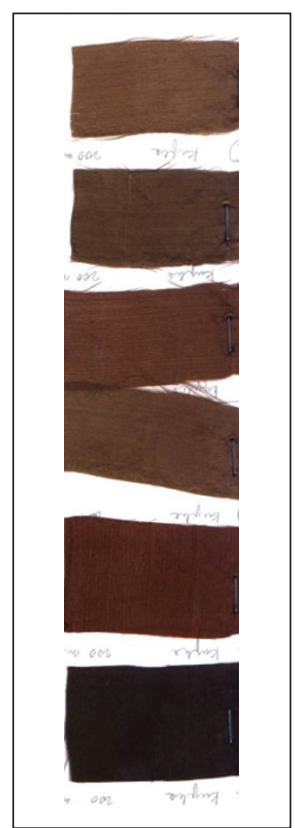

Fotografija 14.a. Marama, uzorci nove svilene tkanine za sanaciju oštećenja (iz fotoarhiva HRZ-a, V. B. Vučković, 2007.) 


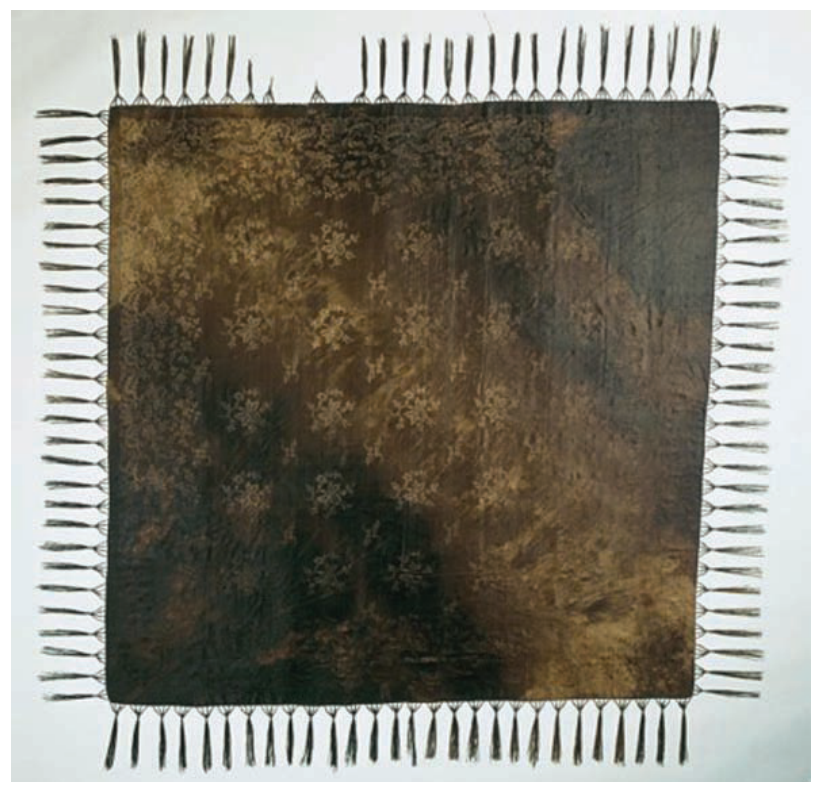

Fotografija 15. Marama, nakon završenih radova (iz fotoarhiva HRZ-a, J. Kliska, 2007.)

\section{Šal pok. Ane Erlinger ${ }^{14}$}

\section{Opis predmeta (fotografija 16)}

Šal pokojne Ane Erlinger ima oblik vrlo izduženog i uskog pravokutnika, a izrađen je od svilenog damasta smeđocrvene boje te je ukrašen resama od smeđeg svilenog konca izvedenima tehnikom uzlanja. Tkanina ima utkani uzorak s paralelnim prugama i cvjetnim buketima koji teče uz rubove šala. Šal je nepoznate provenijencije, a može se datirati oko 1845. godine u skladu s datacijom haljine uz koju je pronađen..$^{15}$

\section{Tekstilno-tehnološke karakteristike marame}

Šal je dimenzija 264 x $56 \mathrm{~cm}$ s resama dužine 8,3 i $16 \mathrm{~cm}$. Izrađen je od jednog dijela svilene tkanine s očuvanim živim rubovima na obje duže strane. Na kraćim stranama tkanina je rezana i porubljena dvostrukim pregibom u širini od $0,5 \mathrm{~cm}$. Porub je sašiven ručno zrnatim bodom debljim svilenim koncem iste boje kao i os-

14 Izvješće o provedenim konzervatorsko-restauratorskim radovima na marami Ane Erlinger iz kripte katedrale sv. Terezije Avilske u Požegi. Ludbreg: Hrvatski restauratorski zavod - Restauratorski centar Ludbreg, 2011.

15 Izvješće o provedenim konzervatorsko-restauratorskim radovima na haljini Ane Erlinger iz kripte požeške katedrale sv. Terezije Avilske.(2011.) Zagreb: Hrvatski restauratorski zavod, Odjel za tekstil. 
novna tkanina. Na kraćim stranama montirane su ukrasne rese dužine $16 \mathrm{~cm}$ (očuvane samo u tragovima), dok su upola kraće rese, dužine 8,6 cm, montirane samo na jednoj, dužoj strani sa živim rubom. Svilena tkanina smeđocrvenog je tona istkana u saten vezu. Dekorirana je motivima traka i cvjetnih buketa. Ukrašena je debljim i tanjim trakama svijetlosmeđe boje koje se nižu u paralelnim redovima, naizmjenično deblje i dvije-tri tanje u grupi, jedna iznad druge, duž sve četiri strane šala na čijim se uglovima križaju. Deblje i tanje trake svijetlosmeđe su boje. Izvedba motiva traka u smjeru osnove pripremljena je tijekom snovanja izmjenom smeđih i svijetlosmeđih niti, a onih u smjeru potke tijekom tkanja korištenjem svijetlosmeđih potki. Šal je dodatno ukrašen motivima većih ili manjih cvjetnih buketa na unutarnjoj, trostrukoj tankoj traci koji su izvedeni tehnikom broširanja ${ }^{16}$ (fotografija 17). Ukrasne rese izvedene su kombiniranjem dvaju različitih načina uzlanja (fotografija 18).

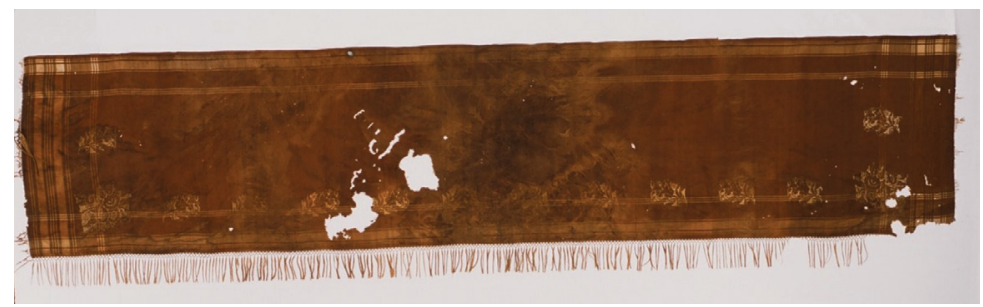

Fotografija 16. Šal, prije radova (iz fotoarhiva HRZ-a, N. Vasić, 2011.)

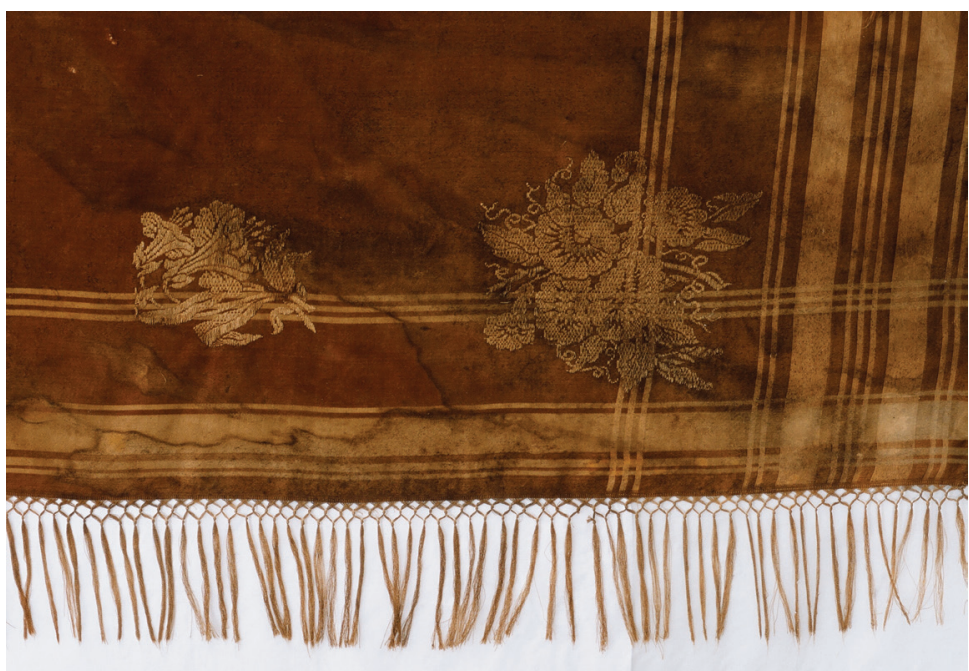

Fotografija 17. Šal, detalj tkanog uzorka (iz fotoarhiva HRZ-a, N. Vasić, 2011.)

${ }_{16}$ Broširanje je tehnika tkanog ukrašavanja umetanjem dodatne niti potke željenog tona ili teksture kojima se utkiva motiv. 


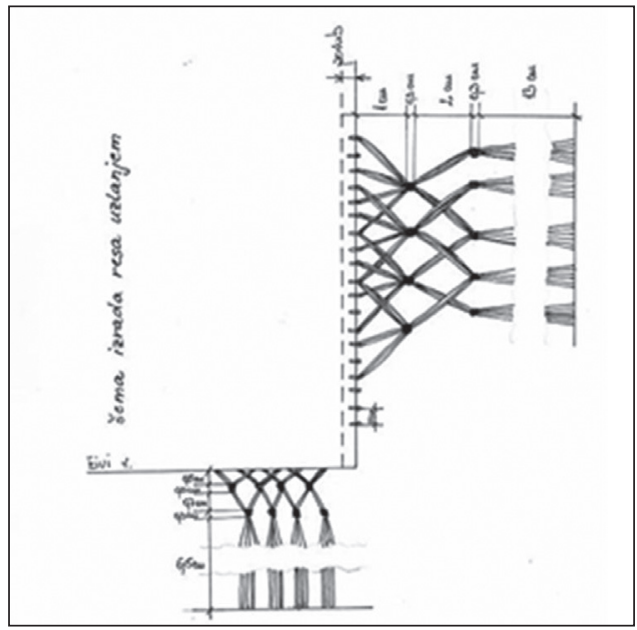

Fotografija 18. Šal, grafički prikaz konstrukcije resa (izradila: V. B. Vučković, 2011.)

\section{Opis zatečenog stanja predmeta}

Nakon prve faze radova na nužnim konzervatorskim postupcima dezinfekcije, mehaničkog uklanjanja nečistoće, mokrog čišćenja i izravnavanja provedenih tijekom 2006. godine zatečeno stanje predmeta bilo je sljedeće (fotografija 20):

- bila su vidljiva fotokemijska oštećenja tkanine i tekstilnih niti;

- na tkanini i resama nastale su promjene izvornog obojenja u vidu mrlja nepravilna oblika. Promjena obojenja najvjerojatnije je bila posljedica neposrednog kontakta tkanine s ljudskim tijelom prilikom procesa raspadanja jer je šal bio omotan oko tijela pokojnice. Izvorni smeđocrveni ton obojenja mjestimice je posvijetlio, a raspon promjene obojenja sezao je od smeđocrvenih do svijetlih, oker i žutih tonova;

- niti osnove i potke bile su izobličene i razmaknute u vidu manjih i većih rupica po površini tkanine (vidi skicu oštećenja);

- niti osnove i potke svilene tkanine kao i resa bile su oslabljene, istrošene i na tim mjestima tkanina je bila tanja i prozirna, a rese stanjene;

- bile su vidljive rupe raznih dimenzija na nekoliko mjesta, a najveće u središnjem dijelu i na jednom kraju (fotografija 21);

- rese su bile oštećene: na užim stranama gotovo su u potpunosti nedostajale, na dužoj su strani bile oštećene, a u predjelu krajnjeg ugla, gdje su vidljiva i oštećenja tkanine, nedostajale su (fotografija 22).

- resama su mjestimično bile oslabljene neke niti, bila je vidljiva promjena tona obojenja, neke su bile zapetljane te onečišćene ostacima čahurica i drugom skorenom prljavštinom. 


\section{Provedeni konzervatorsko-restauratorski radovi}

Tijekom 2010. godine konzervatorsko-restauratorski radovi na predmetu nastavljeni su na Odsjeku za tekstil Restauratorskog centra u Ludbregu sličnim redoslijedom kao i na marami Ane Slavetić. ${ }^{17}$

a) Čišćenje tkanine

Temeljito pranje i čišćenje provedeno je u prvoj fazi radova kao i na marami, a postupak dodatnog uklanjanja preostalih dijelova čahurica, stranih vlakana te ostataka pokidanih i oštećenih / oslabljenih vlakana tkanine šala proveden je na isti način kao i na marami.

b) Izravnavanje tekstilnih niti tkanine

Tkaninu šala bilo je potrebno i dodatno izravnati jer su pojedini dijelovi tkanine, tj. niti osnove i potke, bili izgubili svoju formu i iskrivili se (posebno na mjestima gdje tkanina nedostaje). U tu svrhu ponovljen je postupak koji je primijenjen i na marami (fotografija 19).

c) Bojadisanje tkanine za podlaganje i šivanje

Za potrebe podlaganja oštećenih dijelova tkanine šala korištena je nova svilena tkanina tvorničkog naziva Epinal kao i za prethodno opisane radove na marami. Postupak bojadisanja tkanine bio je uobičajen, $s$ tom razlikom što je napravljeno šest uspješnih proba bojadisanja i sukladno tome uslijedilo je bojadisanje tkanine $\mathrm{u}$ šest nijansi smeđe boje. Svila za šivanje obojena je u četiri tona (od svijetle oker do tamnocrvenosmeđe nijanse). Za bojenje su korištene kupke destilirane vode, soli, octa i boja u prahu Marabu leicht \& bunt - Batik und Färbefarbe (žutonarančaste, narančastocrvene, crvenosmeđe, tamnosmeđe, srednjosmeđe, crne, zelenkaste i tamnocrvene). ${ }^{18}$

d) Zatvaranje oštećenja kombiniranom tehnikom (fotografije 25 i 25a)

Oštećenja tkanine sanirana su polaganjem većih ili manjih fragmenata bojene svile s poleđine na mjesta oštećenja istim postupkom i redoslijedom kako je to opisano za maramu (fotografije 23, 24, 25).

\section{e) Sanacija oštećenja na resama}

Budući da su rese na šalu bile u sličnom zatečenom stanju kao i na marami (isprepletene i slijepljene jer je na njima bilo još zaostalih komadića čahurica i otpalih, odumrlih vlakana), provedena je relaksacija, dodatno čišćenje, izravnavanje i sanacija oštećenih dijelova. Pri tome je ponovljen postupak opisan za maramu. Nedostajući dijelovi resa nisu nadomještani. Nakon sušenja prišlo se sanaciji.

\footnotetext{
17 Radove su izvodile: Venija Bobnjarić-Vučković (konzervator savjetnik i voditelj radova), Tajana Piškor (suradnik restauratora višeg tehničara) i Maja Vrtulek (viši konzervator-restaurator).

18 Originalni tvornički nazivi bojila u prahu iz serije Marabu leicht $\mathcal{E}$ bunt su: maisgelb (021), rotorange (023), cognac (027), dunkel braun (045), mittel braun (046), schwarz (073), sapin (275), bordeaux (034).
} 
f) Izrada fotografske i grafičke dokumentacije

Prije početka radova i tijekom radova vođena je detaljna fotografska dokumentacija sa snimkama totala i svih karakterističnih detalja oštećenja te faza radova, a po završenim radovima i fotografije stanja nakon radova.

Izrađena je grafička dokumentacija, i to: skica konstrukcije šala, skica uzlanja/ montaže resa, skica oštećenja i provedene sanacije; šal je precrtan na Melinex foliju u mjerilu $1: 1 \mathrm{~s} \mathrm{ucrtanim}$ točnim dimenzijama, oštećenjima i mjestima sanacije.

g) Pakiranje i transport

Za potrebe sigurnog transporta i privremenog čuvanja šal je zapakiran na isti način kao i marama pok. Ane Slavetić.

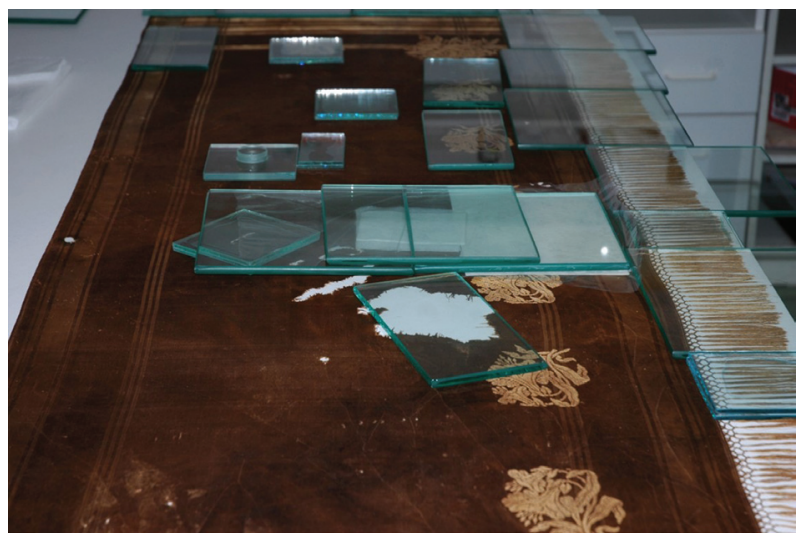

Fotografija 19. Šal, izravnavanje tkanina I resa (iz fotoarhiva HRZ-a, V. B. Vučković, 2011.)

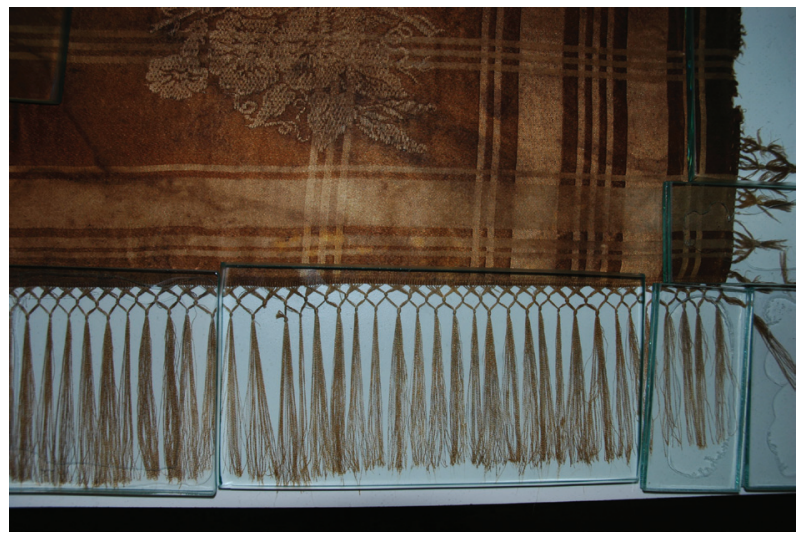

Fotografija 19.a. Šal, izravnavanje resa (iz fotoarhiva HRZ-a, V. B. Vučković, 2011.) 


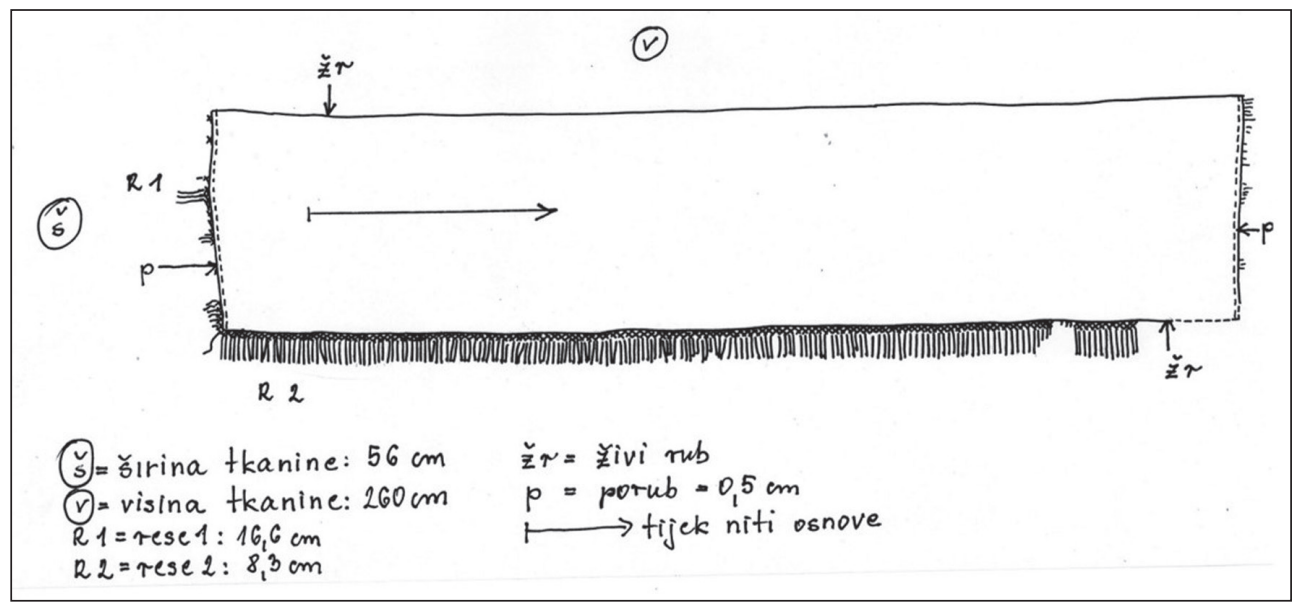

Fotografija 20. Šal, grafički prikaz mehaničkih oštećenja (izradila: V. B. Vučković, 2011.)

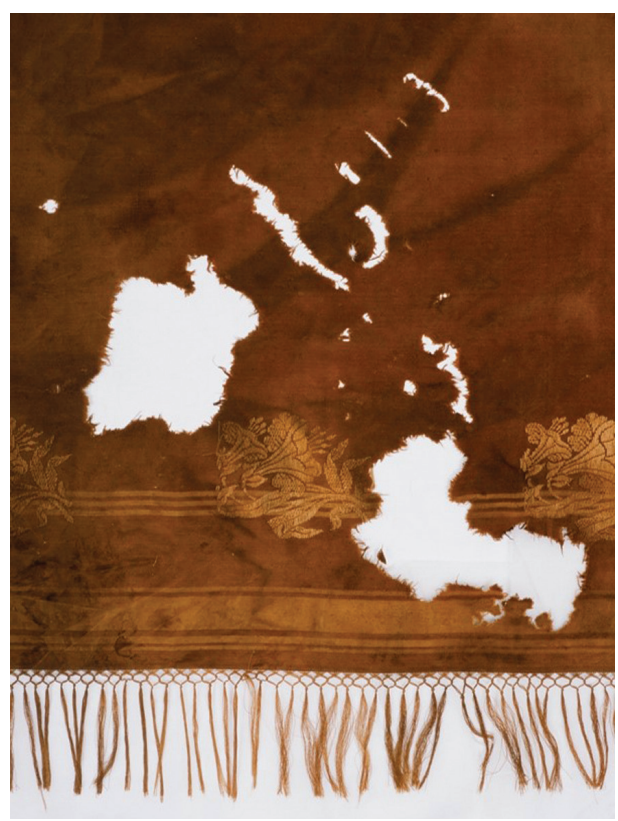

Fotografija 21. Šal, detalj mehaničkih oštećenja tkanine (iz fotoarhiva HRZ-a, N. Vasić, 2011.)

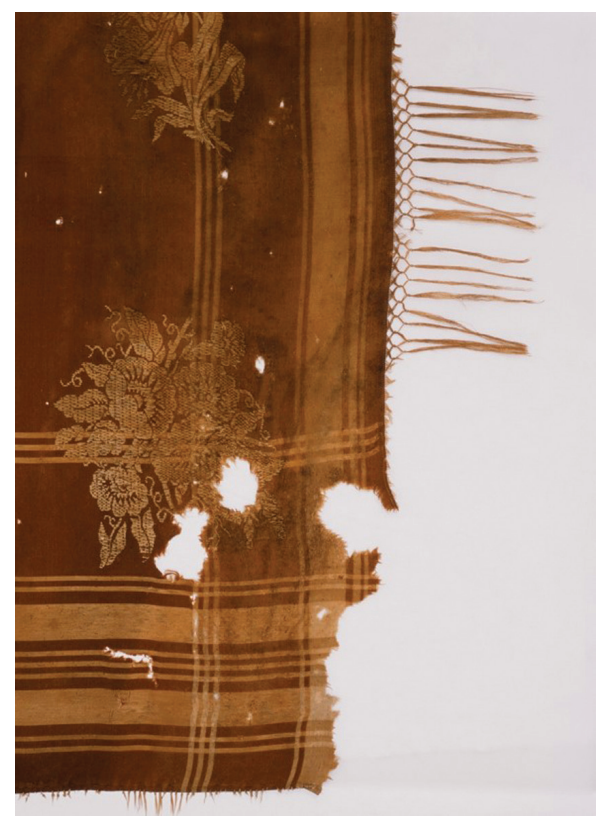

Fotografija 22. Šal, detalj mehaničkih oštećenja ruba tkanine I resa (iz fotoarhiva HRZ-a, N. Vasić, 2011.) 


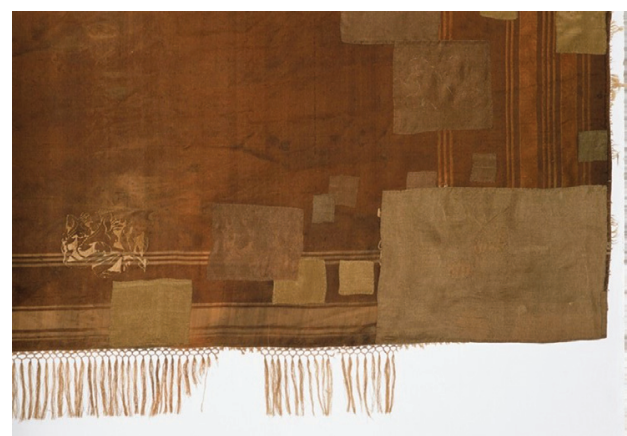

Fotografija 23. Šal, poleđina tkanine nakon sanacije ruba

(iz fotoarhiva HRZ-a, N. Vasić, 2011.)

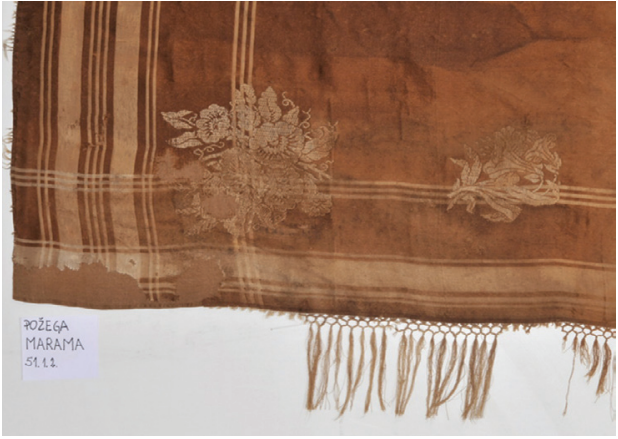

Fotografija 24. Šal, prednja strana tkanine nakon sanacije ruba

(iz fotoarhiva HRZ-a, N. Vasić, 2011.)

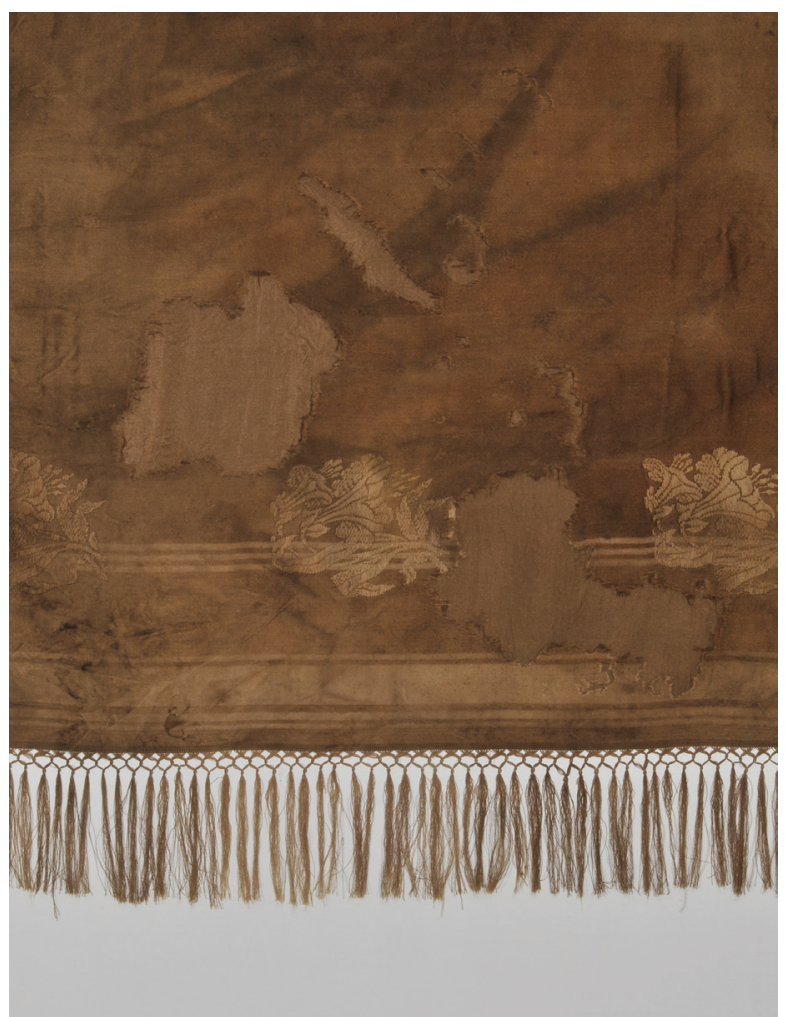

Fotografija 24.a. Šal, prednja strana tkanine nakon sanacije oštećenja (iz fotoarhiva HRZ-a, N. Vasić, 2011.) 


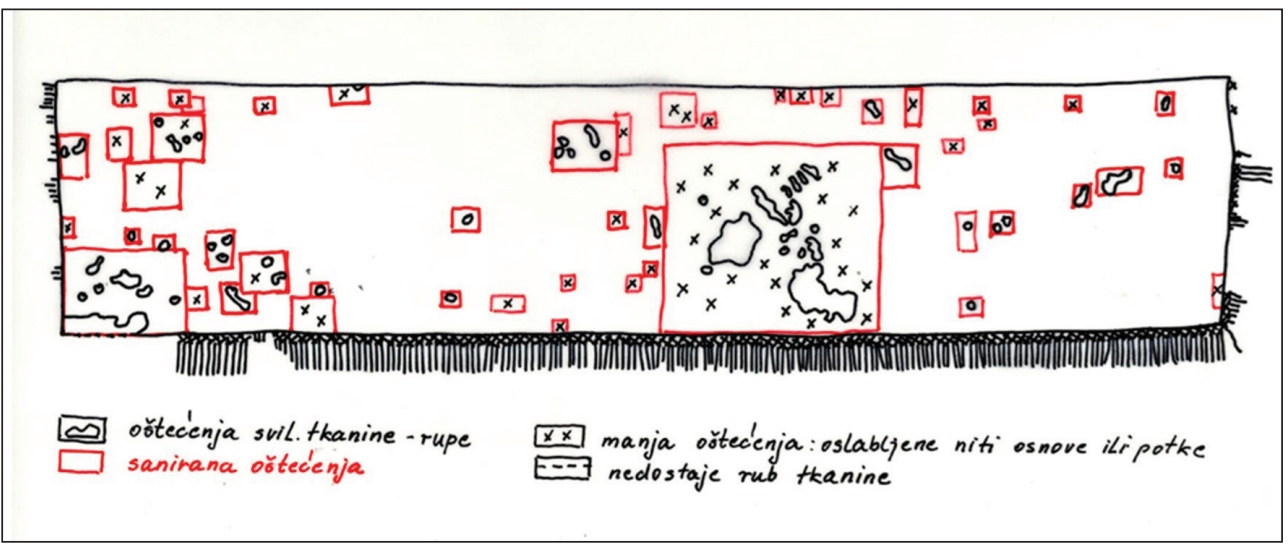

Fotografija 25. Šal, grafički prikaz saniranih oštećenja (izradila: V. B. Vučković, 2011.)

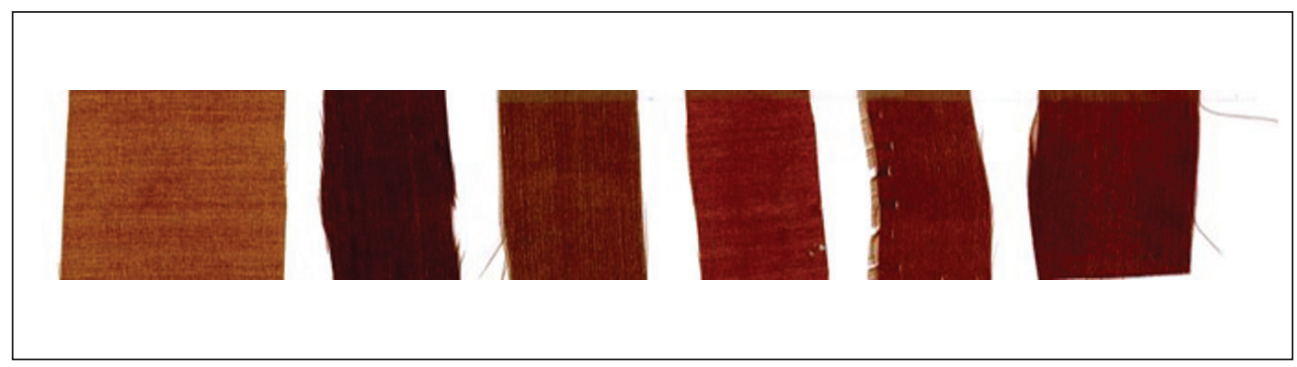

Fotografija 25.a. Šal, uzorci nove svilene tkanine za sanaciju oštećenja (iz fotoarhiva HRZ-a, V. B. Vučković, 2011.)

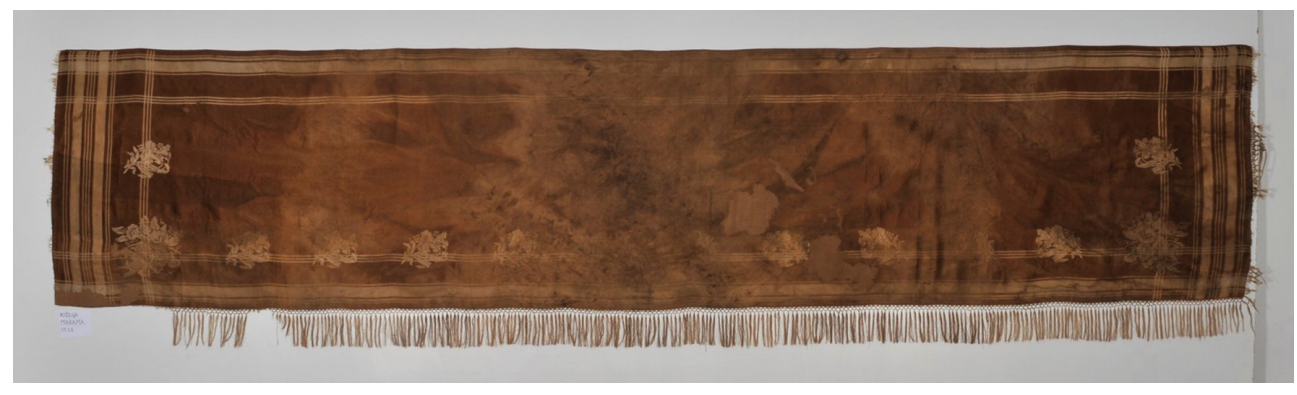

Fotografija 26. Šal, nakon radova (iz fotoarhiva HRZ-a, N. Vasić, 2011.) 


\section{Zaključak}

Marame velikog formata od fine, mekane i sjajne svilene, damastne tkanine bile su moderne od kraja 18. stoljeća do 60-ih godina 19. stoljeća. Žene su ih koristile kao dekorativni dodatak haljinama, ali su ih ujedno štitile od hladnoće. Iz primjera haljina, marame i šala pronađenih uz pokojnice u ljesovima iz kripte katedrale sv. Terezije Avilske evidentno je da su Požežanke i u 19. stoljeću pratile europske modne trendove. Tijekom konzervatorsko-restauratorskih radova predmetima je vraćen izvorni izgled, a tkaninama mekoća i sjaj, pa je na taj način bilo moguće provesti analize tehnoloških karakteristika tkanina kao i konstrukcijske analize haljina i njima pripadajućih marame i šala. Svi predmeti ističu se visokom kvalitetom svilenih tkanina u rasponu boja od bjelokosne do tamne, smeđe boje. Marama i šal se po tonovima obojenja, motivima čipki, cvjetnih buketa i paisley motiva uklapaju u uobičajene trendove ukrašavanja i dizajna razdoblja od prve polovice do sredine 19. stoljeća te se mogu uvrstiti u stilsko razdoblje romantizma, a najkasnije u 30-e ili 40-e godine 19. stoljeća. Može se pretpostaviti da su predmeti ili same tkanine najvjerojatnije izrađeni / istkani u nekoj od srednjoeuropskih tkaonica svile, ali je točno porijeklo teško utvrditi. No, ako se tkanine i na njima utkani motivi marama usporede s dokumentiranom građom iz Muzeja primijenjenih umjetnosti u Beču ${ }^{19}$, gdje se čuvaju knjige uzoraka tkanina iz bečkih tkaonica svile 19. stoljeća, uočavaju se vrlo srodna likovna i tehnološka rješenja. To bi moglo upućivati na zaključak da su tkanine za maramu i šal, ili već gotovi proizvodi, bili nabavljeni / uvezeni s područja srednje Europe (što je vrlo vjerojatno Beč) s obzirom na to da su dobro poznate gospodarske, kulturne i trgovinske veze sjevernih hrvatskih krajeva s Habsburškom Monarhijom, a potom i Austro-Ugarskom Monarhijom te područjima koja su bila u njezinu sastavu (fotografija 27).

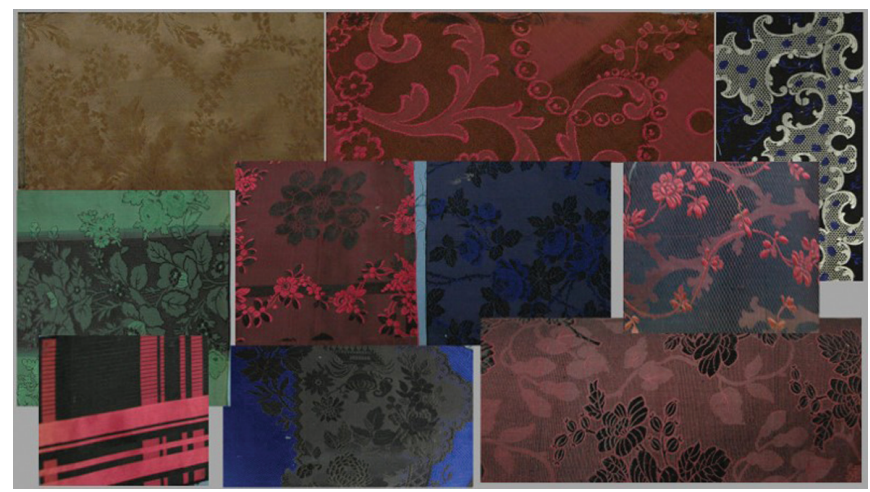

Fotografija 27. Uzorci tkanina iz bečkih tkaonica svile u 19. stoljeću (iz fotoarhiva HRZ-a, V. B. Vučković, 2011.)

19 Fotografije uzoraka tkanina iz Knjige uzoraka za prodaju tkanina (Muster collection) koja se čuva u Muzeju primijenjene umjetnosti (Museum für angewandte Kunst) u Beču, fotografirani su prilikom studijskog boravka autorice u Beču u studenom 2011. godine. 


\section{Literatura i izvori}

Čunko, R.-Pezelj, E. (2002.) Tekstilni materijali. Čakovec: Tekstilno-tehnološki fakultet u Zagrebu.

Laver, J. (1988.) Costume E Fashion - A Concise History. London: Thames and Hudson inc. Peacock, J. (2007.) Povijest odijevanja na zapadu. Zagreb: Golden Marketing - Tehnička knjiga Zagreb.

Thiel, E. (1963.) Geschichte des Kostumes. Berlin: Henschelverlag.

Dres Code-mode von 1570. bis 1960. (2005.) Graz: Landesmuseum Joanneum,

Izvješće o provedenim konzervatorsko-restauratorskim radovima na grobnom tekstilu iz kripte katedrale Sv. Terezije Avilske, Požega (haljina Ane Ljubić, haljina i marama Ane Slavetić. Zagreb: Hrvatski restauratorski zavod, Odjel za tekstil, 2008.

Izvješće o provedenim konzervatorsko-restauratorskim radovima na marami Ane Slavetić iz kripte katedrale sv. Terezije Avilske u Požega. Ludbreg: Hrvatski restauratorski zavod - Restauratorski centar Ludbreg. (2008.).

Izvješće o provedenim konzervatorsko-restauratorskim radovima na marami Ane Erlinger iz kripte katedrale sv. Terezije Avilske u Požegi. Ludbreg: Hrvatski restauratorski zavod - Restauratorski centar Ludbreg (2011.).

Izvješće o provedenim konzervatorsko-restauratorskim radovima na haljini Ane Erlinger iz kripte požeške katedrale Sv. Terezije Avilske. Zagreb: Hrvatski restauratorski zavod, Odjel za tekstil (2011).

Nužni konzervatorski postupci na tekstilnim predmetima iz kripte katedrale Sv. Terezije u Požegi /plakat/ Zagreb: Hrvatski restauratorski zavod (2014.).

Svileni tragovi. / katalog izložbe/ Požega: Konzervatorski odjel Ministarstva kulture u Požegi (2014.).

apretura. http://www.enciklopedija.hr/Natuknica.aspx?ID=3404 / Pristupljeno 14. 9. 2020.

Batiste. https://en.wikipedia.org/wiki/Batiste / Pristupljeno 8. 2. 2020.

Batiste. https://stylerevolution.github.io/textilegloss / Pristupljeno 14. 9. 2020.

Calico. https://en.wikipedia.org/wiki/Calico / Pristupljeno 8. 2. 2020.

Muslin. https://www.britannica.com/print/article/399430/Muslin / Pristupljeno 8. 2. 2020. Napoleon III http://www.enciklopedija.hr/ Natuknica. aspx ?ID=42928 / Pristupljeno 14. 9. 2020.

Shawl. www.britannica.com/eb/article-9067190/shawl / Pristupljeno 15. 2. 2008.

Shawls. www.victoriana.com/Cashmere/Cashmere-shawls.html / Pristupljeno 8. 4. 2011. 


\section{Conservation and Restoration of Two Scarves from the Crypt in the Cathedral of St. Teresa of Avila in Požega}

\section{Summary}

During the restoration of the crypt in the Cathedral of St. Teresa of Avila in Požega, a large number of grave goods were found in wooden coffins with the remains of the citizens of Požega, including well-preserved clothes they had been buried in. Among the preserved textile items, there were two scarves that belonged to Ana Slavetic and Ana Erlinger, made out of fine, soft, glossy silk damask fabric in brown tones with woven motifs of flower bouquets and lace. Both the conservation- and restoration-related research and comparative analyses of textile, technological and stylistic characteristics were aimed at determining the type and origin of the silk fabrics, which were dated in the first half of the $19^{\text {th }}$ century based on the results obtained. It was however not possible to determine the exact location of their production. Nevertheless, based on comparison with other comparable examples, it may be presumed they had been purchased in Central Europe - in Austria (Vienna) or the Czech Republic, as at that time, continental Croatia had had intensive economic, trade and cultural ties with these areas.

Although fairly well preserved in their entirety, the scarves suffered considerable mechanical damage and physio-chemical changes to the original colour tones due to the conditions these textile items had been exposed to during the decomposition of the bodies. In 2006, the Department for Textiles of the Croatian Conservation Institute in Zagreb carried out the disinfection, wet and dry cleaning, drying and pressing of the entire collection of dresses and scarves, whilst during 2009 and 2010, conservation and restoration of the two scarves was continued and completed by the Section for Textiles of the Conservation Department of the Croatian Conservation Institute in Ludbreg.

The items have been cleaned from the remaining particles of impurity; fabrics and fringes have ben straightened, and mechanical damage has been repaired using a combined technique of lining and fastening. After the reparation work had been conducted, the items were returned to Požega packed in infinity cardboard storage boxes.

Keywords: Cathedral of St. Teresa of Avila; grave textiles; silk damask; scarf; shawl; conservation and restoration works.

Venija Bobnjarić-Vučković, prof. povijesti i umjetnosti i etnolog

Hrvatski restauratorski zavod, Restauratorski odjel Ludbreg

Trg Sv. Trojstva 15, 42230 Ludbreg

vouckovic@hrz.hr 